\title{
PENERAPAN MODEL GROUP INVESTIGATION BERBASIS KONTEKSTUAL PADA PEMBELAJARAN FISIKA DI SEKOLAH MENENGAH ATAS
}

\author{
Prayudi \\ SMA Negeri 3 Lumajang \\ Email: prayudi_sman3lmj@yahoo.com
}

\begin{abstract}
Abstrak
Tujuan penelitian adalah: (1) untuk meningkatkan hasil belajar melalui penerapan model Group Investigation dalam pelajaran Fisika, (2) mengetahui respon siswa terhadap penerapan model Group Investigation dalam pelajaran Fisika, dan (3) mengetahui kendala yang mungkin terjadi dalam penerapan model Group Investigation. Penelitian dilaksanakan di SMA Negeri 3 Lumajang dengan pendekatan kualitatif dan kuantitatif bersifat deskriptif. Data penelitian berupa observasi, tes dan angket. Hasil penelitian menunjukkan: (1) penerapan model Group Investigation dapat meningkatkan hasil belajar siswa dari rata-rata 73,40 dengan daya serap $73,40 \%$ dan ketuntasan belajar $57,10 \%$ pada siklus 1 , meningkat menjadi rata-rata 76,1 dengan daya serap $76,10 \%$ dan ketuntasan belajar $82,80 \%$ pada siklus 2 ; (2) penerapan model pembelajaran Group Investigation dapat menumbuhkan respon positif siswa dengan rata-rata respon siswa 36,8 pada siklus 1 menjadi 38,7 pada siklus 2; (3) penerapan model Group Investigation dalam pelajaran Fisika mengalami beberapa kendala pada siklus 1 yaitu masih terdapatnya anggota kelompok yang kurang aktif dan ragu dalam mengemukakan pendapat.
\end{abstract}

Kata kunci: Group Investigation, hasil belajar, respon positif

\begin{abstract}
The aims of the research are: (1) to improve the learning result through the application of Group Investigation model on Physics Lesson, (2) to know the response of students to the application of the Group Investigation Model on Physics lesson, and (3) to determine the problems that may occur in the application of the Model Group Investigation. The research is conducted at State Senior High School (SMAN) 3 Lumajang with qualitative and quantitative descriptive method. The data is collected by using observations, tests and questionnaires. The findings showed (1) the application of Group Investigation Model can improve the learning results of the student with the average value of 73.40 and the average absorption value of $73.40 \%$ and learning mastery value of $57.10 \%$ in cycle 1 into the average value of 76.1 with the average absorption value of $76.10 \%$ and learning mastery value of $82.80 \%$ in cycle 2; (2) the application of the Group Investigation Model also brought positive response from the student with average student response value 36.8 in cycle 1 into 38.7 in cycle 2; (3) The application of the Group Investigation Model on Physics Lesson is showing some problems in cycle 1 with the given evidence that some members of the groups are showing less active role and showing anxiety in expressing opinions.
\end{abstract}

Keywords: Group Investigation, learning result, positive response

\section{PENDAHULUAN}

Pendidikan adalah tiang untuk mampu mendukung pembangunan di masa depan bagi bangsa Indonesia. Pendidikan yang mampu mendukung pembangunan di masa depan adalah pendidikan yang mampu mengembangkan potensi peserta didik. Untuk mensukseskan tujuan tersebut maka 
guru harus mampu memilih dan menerapkan model, metode atau strategi pembelajaran yang sesuai dengan karakteristik materi sehingga mampu mengembangkan daya nalar siswa secara optimal, sehingga siswa mampu semangat mengikuti pembelajaran dan tidak merasa bosan (Pertiwi, dkk, 2013)

Pembelajaran adalah proses yang sengaja dirancang untuk menciptakan terjadinya aktivitas belajar dalam diri individu (Pribadi, B. 2009). Dengan kata lain, pembelajaran merupakan sesuatu hal yang bersifat eksternal dan sengaja dirancang untuk mendukung terjadinya proses belajar interval dalam diri individu. Pembelajaran Fisika tidak semata-mata berupa alih pengetahuan saja dari guru ke siswa, tetapi diharapkan siswa juga mengetahui bagaimana cara ilmu itu diperoleh agar mereka memiliki keterampilan sesuai dengan tujuan mempelajari Fisika di sekolah sehingga dapat memecahkan persoalan Fisika (Irianti, dkk, 2007).

Salah satu permasalahan pembelajaran Fisika adalah minat belajar para siswa dalam mengikuti pembelajaran masih kurang dalam kegiatan belajar siswa cenderung pasif dan hanya menerima informasi atau sajian materi yang diberikan oleh guru. Penggunaan metode ceramah dalam kegiatan pembelajaran menunjukkan bahwa siswa masih terlihat kurang aktif dan kesulitan dalam belajar fisika sehingga tingkat kemampuan siswa dalam mengembangkan pola pikir dalam memahami suatu materi masih rendah. Hal ini tentu saja menyebabkan hasil belajar para siswa menjadi rendah.

Berdasarkan permasalahan tersebut, maka pemilihan metode pembelajaran yang sesuai dengan kebutuhan dan keadaan siswa perlu dipilih dan diterapkan untuk mampu meningkatkan hasil belajar dan menumbuhkan respon positif siswa. Dalam penelitian ini peneliti akan mencoba menerapkan model pembelajaran kooperatif tipe Group Investigation. Menurut Moedjiono, dkk (1992) bahwa keunggulan strategi model pembelajaran Group Investigation yaitu siswa tidak terlalu bergantung pada guru, akan tetapi dapat menambah kepercayaan, kemampuan berpikir sendiri untuk mengembangkan informasi dari berbagai sumber, untuk menyelesaikan dan memecahkan suatu masalah, sehingga semua anggota kelompok memahami. Dengan penerapan model tersebut juga mampu melatih siswa untuk mampu bekerja-sama dengan penuh tanggung jawab dan dapat mengasah kemampuan siswa dalam mengeluarkan ide-ide atau pemikiran yang dimilikinya.

Strategi pembelajaran yang baik adalah ketika tercipta suasana pembelajaran yang kondusif bagi tercapainya tujuan pendidikan. Selain itu, strategi pembelajaran juga harus memperhitungkan semua kondisi siswa, baik itu keadaan internal maupun eksternal siswa. Model Group investigation seringkali disebut sebagai metode pembelajaran kooperatif yang paling kompleks. Hal ini disebabkan oleh metode ini memadukan beberapa landasan pemikiran, yaitu berdasarkan pandangan konstruktivistik, democratic teaching, dan kelompok belajar kooperatif.

Berdasarkan pandangan konstruktivistik, proses pembelajaran dengan model group investigation memberikan kesempatan seluas-luasnya kepada siswa untuk terlibat secara langsung dan aktif dalam proses pembelajaran mulai dari perencanaan sampai cara mempelajari suatu topik melalui investigasi. Democratic teaching adalah proses pembelajaran yang dilandasi oleh nilai-nilai demokrasi, yaitu penghargaan terhadap kemampuan, menjunjung keadilan, menerapkan persamaan kesempatan, dan mem- 
perhatikan keberagaman peserta didik (Budimansyah, 2007: 7).

Group Investigation merupakan salah satu bentuk pembelajaran kooperatif yang menekankan pada partisipasi dan aktivitas siswa untuk mencari sendiri materi (informasi) pelajaran yang akan dipelajari melalui bahan-bahan yang tersedia, misalnya dari buku pelajaran atau siswa dapat mencari melalui internet. Siswa dilibatkan sejak perencanaan, baik dalam menentukan topik maupun cara untuk mempelajarinya melalui investigasi. Tipe ini menuntut para siswa untuk memiliki kemampuan yang baik dalam berkomunikasi maupun dalam keterampilan proses kelompok. Model Group Investigation dapat melatih siswa untuk menumbuhkan kemampuan berfikir mandiri. Keterlibatan siswa secara aktif dapat terlihat mulai dari tahap pertama sampai tahap akhir pembelajaran.

Dalam metode Group Investigation terdapat tiga konsep utama, yaitu: penelitian atau enquiri, pengetahuan atau knowledge, dan dinamika kelompok atau the dynamic of the learning group, (Udin S. Winaputra, 2001:75). Penelitian di sini adalah proses dinamika siswa memberikan respon terhadap masalah dan memecahkan masalah tersebut. Pengetahuan adalah pengalaman belajar yang diperoleh siswa baik secara langsung maupun tidak langsung. Sedangkan dinamika kelompok menunjukkan suasana yang menggambarkan sekelompok saling berinteraksi yang melibatkan berbagai ide dan pendapat serta saling bertukar pengalaman melaui proses saling beragumentasi.

Eggen \& Kauchak (dalam Maimunah, 2005: 21) mengemukakan Group investigation adalah strategi belajar kooperatif yeng menempatkan siswa ke dalam kelompok untuk melakukan investigasi terhadap suatu topik. Dari pernyataan tersebut dapat disimpulkan bahwa metode Group Investigasi mempunyai fokus utama untuk melakukan investigasi terhadap suatu topik atau objek khusus.

Metode Grup Investigation paling sedikit memiliki tiga tujuan yang saling terkait:

1) Group Investigasi membantu siswa untuk melakukan investigasi terhadap suatu topik secara sistematis dan analitik. Hal ini mempunyai implikasi yang positif terhadap pengembangan keterampilan penemuan dan membentu mencapai tujuan.

2) Pemahaman secara mendalam terhadap suatu topik yang dilakukan melaui investigasi

3) Group Investigasi melatih siswa untuk bekerja secara kooperatif dalam memecahkan suatu masalah. Dengan adanya kegiatan tersebut, siswa dibekali keterampilan hidup (life skill) yang berharga dalam kehidupan bermasyarakat. Jadi guru menerapkan model pembelajaran Group Investigasi dapat mencapai tiga hal, yaitu dapat belajar dengan penemuan, belajar isi dan belajar untuk bekerjas secara kooperatif.

Sharan (dalam Supandi, 2005: 6) mengemukakaan langkah-langkah pembelajaran pada model pembelajaran GI sebagai berikut.

1. Guru membagi kelas menjadi beberapa kelompok yang heterogen.

2. Guru menjelaskan maksud pembelajaran dan tugas kelompok yang harus dikerjakan.

3. Guru memanggil ketua-ketua kelompok untuk memanggil materi tugas secara kooperatif dalam kelompoknya.

4. Masing-masing kelompok membahas materi tugaas secara kooperatif dalam kelompoknya.

5. Setelah selesai, masing-masing kelompok yang diwakili ketua 
kelompok atau salah satu anggotanya menyampaikan hasil pembahasannya.

6. Kelompok lain dapat memberikan tanggapan terhadap hasil pembahasannya.

7. Guru memberikan penjelasan singkat (klarifikasi) bila terjadi kesalahan konsep dan memberikan kesimpulan.

8. Evaluasi.

Pelaksanaan langkah-langkah pembelajaran di atas tentunya harus berdasarkan prinsip pengelolaan atau reaksi dari metode pembelajaran kooperatif model Group Investigation. Dimana di dalam kelas yang menerapakan model Group Investigation, pengajar lebih berperan sebagai konselor, konsultan, dan pemberi kritik yang bersahabat. Dalam kerangka ini pengajar seyogyanya membimbing dan mengarahkan kelompok menjadi tiga tahap: (1) Tahap pemecahan masalah, (2) Tahap pengelolaan kelas, (3) Tahap pemaknaan secara perseorangan. Tahap pemecahan masalah berkenaan dengan proses menjawab pertanyaan, apa yang menjadi hakikat masalah, dan apa yang menjadi fokus masalah. Tahap pengelolaan kelas berkenaan dengan proses menjawab pertanyaan, informasi apa yang saja yang diperlukan, bagaimana mengorganisasikan kelompok untuk memperoleh informasi itu. Sedangkan tahap pemaknaan perseorangan berkenaan dengan proses pengkajian bagaimana kelompok menghayati kesimpulan yang dibuatnya, dan apa yeng membedakan seseorang sebagai hasil dari mengikuti proses tersebut (Thelen dalam Winataputra, 2001: 37).

Keberhasilan dari penerapan pembelajaran kooperatif dengan metode Group Investigation dipengaruhi oleh faktor-faktor yang kompleks, diantaranya: (1) pembelajaran berpusat pada siswa, (2) pembelajaran yang dilakukan membuat suasana saling bekerjasama dan berinteraksi antar siswa dalam kelompok tanpa memandang latar belakang, (3) siswa dilatih untuk memiliki kemampuan yang baik dalam berkomunikasi, (4) adanya motivasi yang mendorong siswa agar aktif dalam proses belajar mulai dari tahap pertama sampai tahap akhir pembelajaran.

Dengan memperhatikan bahws model pembelajaran Group Investigation merupakan suatu kegiatan pembelajaran yang mengarahkan aktifitas kelas berpusat pada siswa dan menyediakan peluang kepada guru menggunakan lebih banyak waktunya untuk melakukan diagnosis dan koreksi terhadap masalah-masalah yang dialami oleh para siswa, maka penelitian ini diarahkan dengan tujuan untuk mengetahui peningkatan hasil belajar siswa kelas XI IPA-2 SMA Negeri 3 Lumajang, mengetahui respon siswa terhadap penerapan model Group Investigation dalam pelajaran Fisika, dan mengetahui kendala yang mungkin terjadi dalam penerapan model Group Investigation.

Kerangka operasional sebagai berikut:

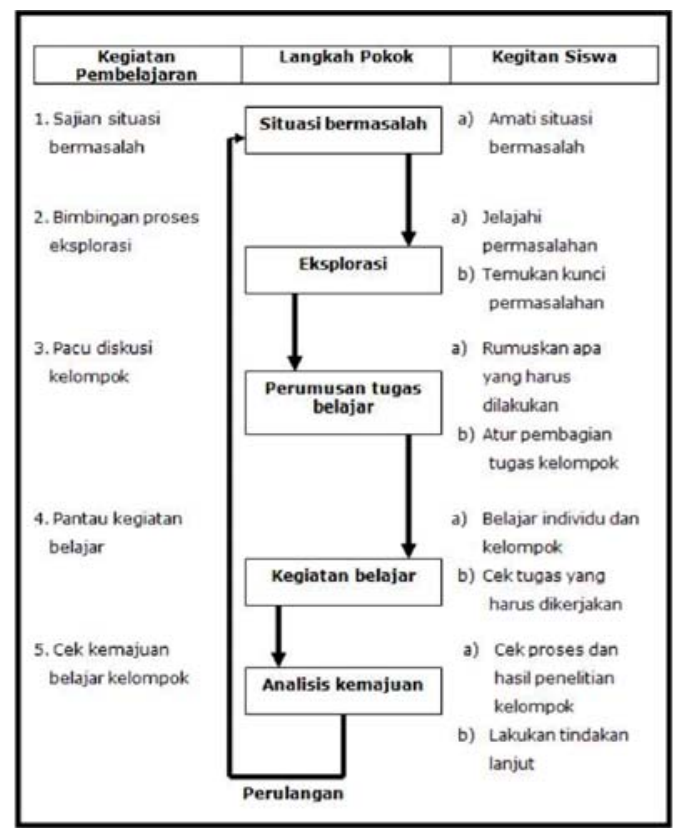

(Sumber : www.kajianpustaka.com-metode pembelajaran, 2012) 
Dari kerangka operasional pembelajaran Group Investigation yang ditulis oleh Joise \& Weil ini dapat kita ketahui bahwa kerangka operasional model pembelajaran Group Investigation adalah sebagai berikut:

1. Siswa dihadapkan dengan situasi bermasalah

2. Siswa melakukan eksplorasi sebagai respon terhadap situasi yang problematis.

3. Siswa merumuskan tugas-tugas belajar atau learning taks dan mengorganisasikan untuk membangun suatu proses penelitian.

4. Siswa melakukan kegiatan belajar individual dan kelompok.

5. Siswa menganalisis kemajuan dan proses yang dilakukan dalam proses penelitian kelompok.

6. Melakukan proses pengulangan kegiatan atau Recycle Activities.

\section{METODE}

Penelitian ini menggunakan teknik Penelitian Tindakan Kelas dengan pendekatan kualitatif yang terdiri dari beberapa siklus. Masing-masing siklus terdiri dari empat tahapan, yaitu: perencanaa tindakan, pelaksanaan tindakan, observasi, dan refleksi (Kemmis dan Mc. Taggart, 1998).

Penelitian ini dilaksanakan di SMA Negeri 3 Lumajang yang beralamatkan di jalan Jenderal Panjaitan No. 79 Lumajang. Subjek penelitiannya adalah siswa kelas XI IPA-2 yang terdiri dari 26 siswa. Penelitian ini dilaksanakan pada bulan September-November semester ganjil tahun ajaran 2013/2014.

Adapun metode yang digunakan dalam pengumpulan data penelitian ini yaitu observasi, tes dan kuesioner atau angket. Menurut Suyanto dan Sutinah (2005:60) kuesioner merupakan daftar pertanyaan terstruktur dengan alternatif jawaban yang telah tersedia sehingga responden tinggal memilih jawaban sesuai dengan aspirasi, persepsi, sikap, atau pendapat pribadinya.

Teknik yang digunakan dalam menganalisis data penelitian ini adalah analisis deskriptif kuantitatif untuk mengetahui hasil belajar dan respon siswa sedangkan untuk mengetahui kendalakendala dan kegiatan diskusi kelompok peneliti melakukan pengamatan sehingga dalam penelitian ini juga menggunakan analisis deskriptif kualitatif. Adapun indikator yang digunakan untuk mengukur keberhasilan penelitian tindakan kelas ini, yaitu: 1) penelitian ini dikatakan berhasil apabila hasil belajar siswa mengalami peningkatan minimal berada pada Kriteria Ketuntasan Minimal (KKM) dan ketuntasan belajar mencapai 80\%; 2) penelitian ini dikatakan berhasil apabila respon siswa mengalami peningkatan dinyatakan secara positif sesuai kriteria penggologan yang telah ditetap-tetapkan.

\section{HASIL DAN PEMBAHASAN}

\section{Hasil Belajar Fisika Siswa melalui Penerapan Model Group Investigation}

Kondisi peserta didik sangat berpengaruh pada hasil belajar yang dicapainya. Kualitas proses belajar yang dilaksanakan oleh pengajar juga sangat berpengaruh terhadap hasil belajar siswa. Setelah peneliti melakukan penelitian dan berdasarkan hasil analisis data yang dilakukan, maka dapat diketahui hasil belajar siswa pada siklus 1 dan siklus 2 dalam grafik di bawah ini.

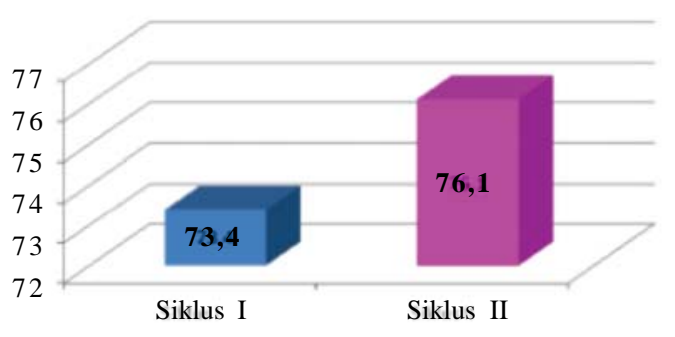

Grafik 1: Hasil Belajar Pada Siklus 1 dan Siklus 2 
Berdasarkan grafik di atas, menunjukkan bahwa hasil belajar siswa pada kelas XI IPA-2 SMA Negeri 3 Lumajang setelah melakukan penelitian tindakan kelas pada siklus 1 memperoleh hasil rata-rata 73,4 dengan daya serap $73,4 \%$ dan ketuntasan belajar mencapai $57,1 \%$. Rata-rata hasil belajar pada siklus 1 ini termasuk kategori baik namun belum memenuhi KKM karena hasil penelitian belum memenuhi KKM atau indikator keberhasilan yang diinginkan maka penelitian dilanjutkan ke siklus 2 .

Pada siklus 2 hasil belajar siswa yaitu rata-rata 76,1 yang tergolong dalam kategori baik dan sudah memenuhi KKM, dengan daya setap 76,1\% dan ketuntasan belajar mencapai 82,8\%. Berdasarkan grafik tersebut, dapat dilihat bahwa penerapan model pembelajaran kooperatif tipe Group Investigation pada siklus 2 sudah mampu meningkatkan hasil belajar sebanyak 2,7 dan penelitian ini dapat dikatakan berhasil, sehingga siklus dapat dihentikan.

\section{Respon Siswa terhadap Penerapan Model Group Investigation}

Untuk mengetahui respon siswa terhadap penerapan model pembelajaran kooperatif tipe Group Investigation dalam penelitian ini dengan pemberian angket diakhir kegiatan siklus. Angket yang disebarkan terdiri atas 10 pernyataan.

Setelah melakukan penelitian tindakan kelas, berikut ini respon siswa terhadap penerapan model pembelajaran kooperatif tipe Group Investigation dalam pembelajaran Fisika pada siklus 1 dan siklus 2 mengalami peningkatan dapat dilihat pada grafik di bawah ini.

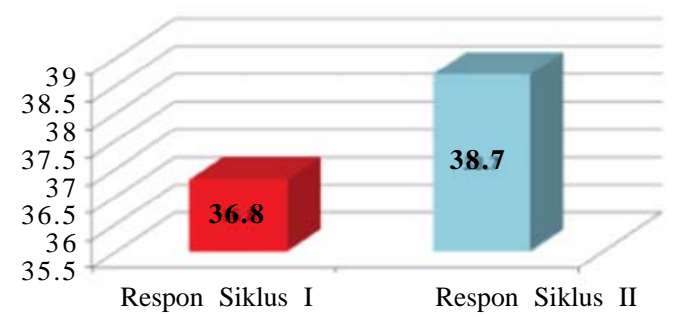

\section{Grafik 2: Respon Siswa Pada Siklus 1 dan Siklus 2}

Berdasarkan grafik di atas, menunjukkan bahwa respon siswa pada siklus 1 rata-rata 36,8 dengan kategori respon positif. Jumlah respon siswa sangat positif 4 orang dengan persentase 14,4\%, respon siswa yang positif berjumlah 16 orang dengan persentase $62,8 \%$ dan respon siswa yang cukup positif berjumlah 6 orang dengan persentase 22,8\%, respon siswa yang kurang positif dan tidak positif persentasenya $0 \%$.

Pada siklus 2 rata-rata respon siswa meningkat menjadi 38,7 yang dikategorikan respon postif. Berikut ini respon siswa yang tergolong sangat positif berjumlah 4 orang dengan persentase $17,1 \%$, respon siswa yang tergolong positif berjumlah 20 orang dengan persentase $77,1 \%$ dan respon siswa yang tergolong cukup positif berjumlah 2 orang dengan persentase $2,8 \%$, sedangkan respon siswa yang kurang positif dan tidak positif persentasenya $0 \%$. Berdasarkan hal tersebut dapat dilihat bahwa respon positif siswa pada siklus 2 mengalami peningkatan sebanyak 1,9 sehingga penelitian dapat dikatakan berhasil.

\section{Kendala-kendala dalam Penerapan} Model Group Investigation

Pelaksanaan siklus 1 peneliti menemukan beberapa kendala yaitu sebagai berikut : (1) pelaksanaan pembelajaran siklus 1 pada pertemuan pertama siswa masih rebut dalam pembentukan kelompok dan belum mampu 
memanfaatkan waktu seefisien mungkin sehingga berpengaruh pada waktu jam pelajaran tersedia, (2) pada pelaksanaan siklus 1 ada anggota kelompok yang kurang aktif dalam hal kerjasamanya untuk mengerjakan tugas diskusi, sehingga tugas yang diberikan lambat terselesaikan, (3) pada pelaksanaan siklus 1 ada anggota kelompok yang ragu dalam mengemukakan pendapat, sehingga kelompok tersebut tidak maksimal mendapatkan nilai yang diinginkan.

Beberapa kendala yang peneliti temukan pada siklus 1 , sudah peneliti carikan pemecahannya untuk melakukan perbaikan-perbaikan sehingga dalam pelaksanaan siklus 2 kendala tersebut tidak terulang lagi. Adapun solusi atau perbaikan yang dilakukan untuk meminimalisir kendala tersebut yaitu : (1) Memberikan nasihat kepada siswa agar tertib selama proses pembelajaran, (2) Guru menekankan bahwa siswa yang aktif dalam diskusi, bertanya, maupun berpendapat akan mendapatkan tambahan nilai dalam kelompoknya, (3) Guru akan mengarahkan dan melatih siswa untuk berani berkomunikasi dengan baik.

Berdasarkan penjelaskan tersebut, dapat disimpulkan bahwa penerapan model pembelajaran kooperatif tipe Group Investigation dalam pelajaran Fisika di kelas XI IPA-2 SMA Negeri 3 Lumajang pada siklus 1 mengalami kendala, dan sudah dapat diatasi dengan melakukan perbaikan-perbaikan sehingga pelaksanaan siklus 2 dapat berjalan dengan baik dan hasil belajar siswa mengalami peningkatan.

\section{SIMPULAN}

Penerapan model pembelajaran kooperatif tipe Group Investigation dapat meningkatkan hasil belajar Fisika pada siswa kelas XI IPA-2 SMA Negeri 3 Lumajang. Hal ini dapat dilihat dari peningkatan hasil belajar siswa pada siklus 1 rata-rata 73,4 daya serap 73,4\% dengan ketuntasan belajar 57,1\% yang tergolong dalam kualifikasi baik namun belum memenuhi KKM sedangkan skor ratarata hasil belajar pada siklus 2 meningkat menjadi 76,1 daya serap 76,1\% dengan ketuntasan belajar 82,8\% yang tergolong dalam kualifikasi baik dan sudah memenuhi KKM.

Penerapan model pembelajaran kooperatif tipe Group Investigation dapat menumbuhkan respon positif siswa pada kelas XI IPA-2 SMA Negeri 3 Lumajang dalam pelajaran Fisika yang terlihat dari adanya peningkatan respon siswa pada setiap siklusnya. Pada siklus 1 diperoleh respon rata-rata 36,8 dan meningkat pada siklus 2 menjadi rata-rata 38,7 dengan kriteria respon positif.

Penerapan model pembelajaran kooperatif tipe Group Investigation dalam pelajaran Fisika di kelas XI IPA-2 SMA Negeri 3 Lumajang mengalami kendala di siklus 1 yaitu : (1) pelaksanaan pembelajaran siklus 1 pada pertemuan pertama siswa masih rebut dalam pembentukan kelompok dan belum mampu memanfaatkan waktu seefisien mungkin sehingga berpengaruh pada waktu jam pelajaran tersedia, (2) pada pelaksanaan siklus 1 ada anggota kelompok yang kurang aktif dalam hal kerjasamanya untuk mengerjakan tugas diskusi, sehingga tugas yang diberikan lambat terselesaikan, (3) Pada pelaksanaan siklus 1 ada anggota kelompok yang ragu dalam mengemukakan pendapat, sehingga kelompok tersebut tidak maksimal mendapatkan nilai yang diinginkan. 
DAFTAR PUSTAKA

Adnyana, I Putu Sudina. (2012). Pengaruh Model Pembelajaran Kooperatif Terhadap Prestasi Belajar Fisika di SMP Negeri 2 Nusa Penida Tahun Pelajaran 2011/2012. Program Studi Teknologi Pembelajaran Program SArjana Universitas Pendidikan Ganesha Singaraja

Irianti, M., Lisma, N. dan RAhmad, M. (2007). Interaksi Belajar Mengajar dalam Pembelajaran Fisika dengan Penerapan Model Pembelajaran Investigasi Kelompok pada Siswa Kelas X SMA Negeri 1 Tambang Kampar. Jurnal Geliga Sains [Online], vol 1, 6 halaman.

Kemmis, S., \& Mc Taggart, R. (1998). The Action Research Planner. Victoria: Deakin University Press.

Moedjiono, dkk. (1992). Strategi Belajar Mengajar. Jakarta: Depdikbud

Pertiwi, Dwi Ana. (2013). Penerapan Kooperatif Tipe Group Investigation Untuk Meningkatkan Hasil Belajar dan Menumbuhkan Respon Positif Siswa dalam Pelajaran PKn. Jurusan Pendidikan Pancasila dan Kewarganegaraan Fakultas Ilmu Sosial Universitas Pendidikan Ganesha Singajara

Pribadi, Benny. (2009). Model Desain Sistem Pembelajaran. Jakarta: Dian Rakyat. 